\title{
Sportsmen Photos in Newspapers: Comparison between China, France and Tunisia.
}

\author{
Abdelhakim Cherif ${ }^{1,2}$; Fairouz Azaiez ${ }^{2,3}$; Nasr Chalghaf ${ }^{2}$; Karim Achour $^{2}$; \\ Laurianne Burlet ${ }^{1}$; Eric De Leseleuc ${ }^{1}$ \\ 1-Laboratory Health, Education and situation of Handicap, University Montpellier I. \\ 2-Higher institute of Sport and the Physical Education of Sfax (Tunisia). \\ 3-Studies Group of Development and Social Environment (Faculty of Letters and Social Sciences of Sfax).
}

\begin{abstract}
Abstact: Theparalympic games are regarded as a major sporting event, the second largest in the world after the Summer Olympic games. The study we conducted is part of the research on social representations of disability and identity building among disabled persons. Indeed through a comparative approach between three countries with different cultures which are China, France and Tunisia, this work puts the point on the differences and similarities which arise through the photographic analysis of the newspaper industry of the Paralympic games of 2008. Concretely, there is a lack of studies relating the quantitative differences that exist in the way which the Paralympic athletes female and male are represented. TheStatistical analysis of pictures used in this work, first gave us a first look at the treatment of disabled athletes in Tunisia, a field, which until the time unexplored, then compare the results found with the work of other researchers in the discipline.
\end{abstract}

Key Words: Social representations, Handicap, Media cover.

\section{Introduction}

The purpose of this study is to analyze the iconographic media coverage of the Paralympic Games of Beijing in newspapers in three countries: China, France and Tunisia,July 28th, 1948; when London is ready to host the Summer Olympic games, the doctor Ludwing Guttmann (known as the father of sport for people with disabilities), decided to organize the Stoke Mandeville Games, the first national competition for people with motor handicap. Only archery was then practiced. 60 years later, during the Beijing Olympics, the number of sporting event was multiplied by 20 .

Guttmann dreamed of a world competition gathering all the people having a disability which is held every four years, a competition which resembles the Olympic Games. 12 years later, at the time of thegames of Rome, its dream became a reality. Indeed more than 400 disabled athletes coming from 103 different countries took part in the first" Paralympic victory of the sport ".Since 1960 and until today, the sport for disabled people did not cease increasing and to diversify, indeed the sets of 2008 knew the participation of more than 4200 athletes coming from 148 countries.

This high inflation has been accompanied by an official discourse that emphasizes "an egalitarian logic" and an obligation to grant the Paralympic games as important as the Olympics one. The insistence on the same schedule, the same venues for the events, the installation of the same athletes in the Olympic Village emphasize constantly the egalitarian logic (Léséleuc\& al. 2010).

The advanced speech by the two committees Olympic and Paralympic lets thus think of a media treatment equal between the athletes participating in the two competitions.

\section{The influence of the media sphere}

The influence of the medias on the behavior of the individuals was the subject of research since the end of last century. Indeed Paul Lazarsfeld and his team in the years 1940 stipulate that the message poured by the medias would pass throughout a"cultural filter" depending of the groups of the individuals (ethical community, religious group...).

Lazarsfeld\& Merton (1948) showed that the medias take part in the production and the reproduction of the social representations like to the reinforcements of the attitudes and the existing standards in our society. The latter became one of the sources to which people turn to find their daily discourse that serve to guide their actions (Kellner, 2003). They thus became the vector quasi hegemonic which provide the references, the words and the systems of argumentation which make it possible to the individuals to doself-building and to give direction to the world which surrounds them. In the contemporary society, the medias are not any more one simple vector of communication, but a privileged source conveying the references used daily by the individualsin its identity construction (Léséleuc, 2009; Kaufmann, 2004; Lipovetsky, 2004; Ehrenberg, 1995). 
Thus written especially photography press, appears to have a crucial role since it is one of the most efficient shape our ideas and influence on our behavior (Freund, 1974) .

\section{Sociology of the handicap?}

Lipovesky (1983) advance the idea that this is the post-modern man time, or rather hypermodern. After a first individualism, the lights and the advent of citizen, there would be a few decades since the gradual arrival of a second individualism (Corcuff, 2007).

At the beginning of the Sixties, thecontemporain sociologists affirm that we imperceptibly entered in a period calls the post modernity or the hypermodernity, one period characterized bya new individual margins choices, an individualimpuls of reflexivity (Giddens, 1994) and the appearance of new collective forms. For the most critical authors, this phase would develop narcissism and would generate a new pathology, while demolishing the social bond (Lasch, 1979). The consequences of these major changes, that the company underwent, are multiple and constitute a true philosophical and anthropological breaking. One of the major changes is the transformation of relationships to the body, in fact, currently, the body and the individual have become inseparable (Saliba, 1999).We have entered a period where the importance of the body is growing, it is no exaggeration to say that the body is omnipresent in society, it must be aesthetic, efficient and effective (Molénat\& al, 2004).

Like the sports body, it must be tamed. Gradually, the body has become a major tool in the quest for identity of each (Brohm, 2001), and its membership and competitiveness have become a very strong challenge for the contemporary individual who must be efficient every day long as possible (Molénat\& al, 2004). Therefore, more than ever, people take care of their bodies which play an important role in the process identity of the individual (Le Breton, 2005). It is solely responsible for the efficiency, competitiveness and the beauty of her body. The latter became the main instrument of competition and competition between individuals (Le Breton, 2005).We consequently comprises overinvestment body of the contemporary individual and very strong identity issues behind it. These points are important since all bodily norms seem toexclude people living with disabilities, and thus question the place that can be given to people deficient in the media and therefore in society.

\section{Review of literature}

We have today scientific knowledge developed in social psychology and sociology of the handicap (Giami\& al. 1988; Barnes \& al. 1999; Olivier \& al.1998; Bogdan\&al, 1989; Ruiz, 2005) which shows, since many years, which the handicapped people are the subject of overall negativesocial representations (they are "less" that the "normal ones" or the "valid ones"), and that they are thus the subject of a stigmatization form in the society (within the meaning of Goffman, 1963).

Research on the mediatization and the communication (Bourdieu, 1996; Akoun, 1998),showed that the medias play a fundamental role in the production and the reproduction of the social representations, like in the reinforcement of the standards and the attitudes in progress in our companies (Altheide, 1984; Auslander, \&Gold, 1999; Holtzman, 2000).

Furthermore, the mass media is not a simple means of communication among many others. Work on the process of social construction of contemporary individualism show that they are (all media) conveying the preferred source references used daily by the individual in his identity construction (Léséleuc, 2009). Namely, with the loss of power of communities belonging to impose the "right" ways of thinking, speech and behavior (Léséleuc\&al, 2013 in press), individuals must turn to other reference sources. Today, the media (with the family and the school) are the key providers. Finally, as regards more specifically the imaging of disability Stiker (2007) showed that there is a significant corpus of images (film, photographs, pictorial works) putting in scene the handicapped people. These images express speeches carrying the social representations in relation to the temporal context of the societies in which they are produced. But more than that, its analysis shows that to function, these images require that the producers of these speeches (in image) and the recipients (those which receive the images) are holders of the same cultural substrates so that the process of the communication is carried out. The communication through the image, indeed, requires a process of decoding and this capacity of interpretation implies that there is a division of a same culturalsubstrates at the same time by the transmitter and the recipients of the speech (Eco, 1992).

The exploration of the scientific literature on media and disability, even media, disability and sport, Allows the location of Already Established knowledge. Various work was undertaken on the media treatment of disabled people, sporting or not, by the newspaper industry, television, or the cinema (Stiker, 2007).

The results on the mediatization of the handicapped sportsmen show that one speaks little about the women, and especially that they are not shown (Schantz\& Gilbert, 2001).The phenomenon of masking certain types of handicap was also located in a recurring way, masking which touches mainly the mental handicap and the cerebral paralysis (Combrouze, 2000;Marcellini, 2007; Pappous\&al, 2007). 
Moreover, a strong "nationalization" in the media treatment by the newspaper industry of the sport among handicapped people was underlined (Clogston, 1990; Zola, 1991; Léséleuc, 2009). The press of each country has a very strong tendency to speak only about the athletes who represent the country, thus following a nationalist logic.

Consequently our assumptions will be as follows:

-The sporting handicapped ones do not obtain the same place as their male counterparts.

-There is a screening of deficiency.

-There is a strong nationalization of the sports results in the press of each analyzed country.

\section{Method}

The analyzed corpus consists of two newspapers with strong assistantship of each country.It is about China Youth Daily and RenminRibao for China, Le Monde and Le Figaro for France and finally Al Chouroukand LaPressefor Tunisia.One could have chosen to work on sporting magazines (the case of L'Equipe in France) but as in Tunisia and China this type of newspapers does not exist and for reasons of conformity one chose other criteria of selection China Youth Daily and RenminRibao(daily of the people)is today the first daily newspapers of the country with 3 exemplary million each one.

Le Monde is the first French daily newspaper in terms of a number of assistantships, without explicitly asserting left, its line leading is generally affirmative.Conversely, Le Figarosecond French daily newspaper in terms of a number of assistantships is a newspaper openly of right-hand side.

In Tunisia, the daily newspapers are either in Arab language or in French language.Al Chourouk (the sun raise) is the first daily newspaper in Arab language in terms of a number of readers. LaPresse a Tunisian daily newspaper in French language.

The period selected is the period which includes the Paralympic games of 2008, with 5 days before and after the games. This period is justified by the results of the other studies which noted that the majority of the articles and the photographs on the Paralympic games are published during the games (Schantz\& Gilbert, 2001).

\section{Results}

The total number of the collected photos is 529 photos, 497 are from the Chinese newspapers, 16 newspapers and 16 French newspapers Tunisians.

1-Difference treatment between the sportsmen and the sporting handicapped ones. Tab.1- Gender by country $(N R=529)$

\begin{tabular}{lccccccccc}
\hline Gender/Country & \multicolumn{2}{c}{ Total } & \multicolumn{2}{c}{ China } & \multicolumn{2}{c}{ France } & \multicolumn{2}{r}{ Tunisia } & Significance \\
\cline { 2 - 7 } & $N$ & $\%$ & $N$ & $\%$ & $N$ & $\%$ & $N$ & $\%$ & \\
\hline Men & 249 & 47,1 & 239 & 48,1 & 8 & 50,0 & 2 & 12,5 & $\chi^{2}=14.76, d l=4$ \\
Women & 167 & 31,5 & 149 & 30,0 & 8 & 50,0 & 10 & 62,5 & $p<0.01$ \\
Mixed & 113 & 21,4 & 109 & 21,9 & 0 & 0 & 4 & 25,0 & \\
\hline
\end{tabular}

As it is showed by the table (1), in the Chinese newspapers, the number of photos of male handicapped athletes is higher than the number of photos of female handicapped athletes, while in Tunisia, the newspapers published more photos of sporting handicapped women. The French newspapers published the same number of male and female photos. The test of Chi-Square showed a significant difference between the three analyzed countries.

\section{2-Screening of deficiency}

Tab.2- Visibility gold invisibility of disability by country $(N R=529)$

\begin{tabular}{lcccccccccc}
\hline Disability/Country & \multicolumn{2}{c}{ Total } & \multicolumn{2}{c}{ China } & \multicolumn{2}{c}{ France } & \multicolumn{2}{r}{ Tunisia } & \multirow{2}{*}{ Significance } \\
\cline { 2 - 9 } & $N$ & $\%$ & $N$ & $\%$ & $N$ & $\%$ & $N$ & $\%$ & \\
\hline Visiblity of disability & 248 & 46,9 & 234 & 47,1 & 6 & 37,5 & 8 & 50,0 & \multirow{2}{*}{ NS } \\
Invisibility of disability & 281 & 53,1 & 263 & 52,9 & 10 & 62,5 & 8 & 50,0 & \\
\hline
\end{tabular}


The second tableshows a great screening of deficiency in the three countries, indeed, more than half of the photographs do not inform us about the type of handicap. The test of Chi-Squaredoes not show a significant difference between the three analyzed countries.

\section{3-Nationalization of the sports results}

Tab.3:Nationality by country $(N R=529)$

\begin{tabular}{lccccccccc}
\hline \multirow{2}{*}{ Nationality/country } & \multicolumn{2}{c}{ Total } & \multicolumn{2}{c}{ China } & \multicolumn{2}{c}{ France } & \multicolumn{2}{c}{ Tunisia } & \multirow{2}{*}{ Significance } \\
\cline { 2 - 9 } & $N$ & $\%$ & $N$ & $\%$ & $N$ & $\%$ & $N$ & $\%$ & \\
\hline National & 107 & 22,1 & 95 & 19,1 & 5 & 31,2 & 7 & 43,8 & $\chi^{2}=10,27, d l=4$ \\
Foreigner & 126 & 23,8 & 124 & 24,9 & 1 & 6,2 & 1 & 6,2 & $p<0,05$ \\
Uncodeable & 296 & 54,1 & 278 & 56,0 & 10 & 63 & 8 & 50,0 & \\
\hline
\end{tabular}

The table (3) shows that more than half of the photos do not inform us about the nationality of the athletes. The Chinese newspapers show more foreign athletes than national athletes, contrary to France and Tunisia, where the foreign athletes are a minority.The test of Chi-Square watches a significant difference between the three analyzed countries.

\section{Discussion}

The descriptive analysis concerning the number of photos published in the newspapers of the three analyzed countries, showed a great difference between China on the one hand and the two other countries.This can be explained by the fact that it is China which organizes the Paralympicgames of 2008, such is the case of the number of photos published by the Greek newspapers into 2004 (86 photos) in comparison with 2000 (4 photos) and 2008 (22photos) (Léséleuc\&al.2010, Léséleuc\&al, 2013 in press).

We have advanced the assumption of an unequal treatment between the sporting ones and the handicapped sportsmen, this assumption is validated only in China where the female athletes " under are represented " compared to the men, this result goes in the direction of work of (Smith \& Thomas, 2005) when they analyzed the British cover of the Paralympic games. The French newspapers show as many men than women while the Tunisian newspapers expose more female handicapped athletes, they are so represented. This thus confirms with the work of (Jones, 2006) when she analyzed the media cover of the Australian sportsmen of the Sydney games. This "over representation" of the women in the Tunisian newspapers can be explained by what certain politicians call the "policy of instrumentalisation" practised by Tunisia, by building an image of modernity to mark distances compared to the other Maghreb countries (Abbassi, 2007).

The assumption advanced concerning the screening of deficiency in the photos is checked in this study, since the mentally handicapped persons still do not have the right to take part in the Paralympic games, one thought that the physical handicapped athletes were going to be " over represented " in the newspapers, but it is noted that the latter pain to impose their " normality " on the eyes of the journalists.This comes to contradict the results of Combrouze(2000) when it noted that the driving handicap is "over represented" in the newspapers.

The problem of nationalization of the sports results in the medias was dealt with in preceding work only in the Paralympic games, the results of this work confirm with the results of other researchers. There is a nationalization phenomenon of the results as well in Tunisia as in France, one speaks little about the results of foreign sportsmen, this comes to confirm work of Zola, (1991) concerning the results of the American and the foreign handicapped sportsmen in the American press.This phenomenon is non-existent in the Chinese newspapers; indeed, one finds more photos of foreign athletes. That can be explained by the fact that China is the organizing country of the games, and by the voice of its politicians, it did not cease evoking its benevolence and its good reception with respect to the foreigners.

\section{Conclusion}

This work gives a first outline on the difference treatment of the Paralympic games between three countries with different cultures.Indeed, these games are presented like a major event in the diffusion of information and images on the handicap. Sometimes the results showed similarities between the three countries, as compared to the screening of deficiency, but also of the significant differences between China, France and Tunisia concerning the difference in treatment between the male and female handicapped athletes and compared to the nationalization of the sports results.

To conclude, an open prospect interesting for this work would be to widen the corpus and thus to see whether the results found in Tunisia would be similar or not in Algeria and in Morocco. One will be able to thereafter compare our results with the results of other studies relating to Asia and Europe, which will enable us to detect 
the similarities and the differences in connection with social acceptance of the handicapped sportsmen conveyed by thewrittenmedias.

\section{Références}

[1]. Abbassi, D. (2007). Sport, légitimation politique et construction identitaire dans la Tunisie des années 2000, L'année du Maghreb. Numéro3.

[2]. Akoun, A. (1998), Sociologie des communications de masse, Paris, Hachette.

[3]. Altheide, D.L. (1984), Media hegemony: A failure of perspective, Public Opinion Quarterly, 48, 476-490.

[4]. Auslander, G.K. \& Gold, N. (1999). Media reports on disability: A binational comparison of types and causes of disability as reported in major newspapers, Disability and Rehabilitation, 21 (9): 420-431.

[5]. Barnes, C., Mercer, G. \& Shakespeare, T. (1999): Exploring Disability, A Sociological Introduction. Cambridge: Polity.

[6]. Bogdan, R.\& Taylor, S. (1989),Relationships with Severely Disabled People: The Social Construction of Humanness, Social Problems, vol. 36, $\mathrm{n}^{\circ}$ 2, avril, 135-148.

[7]. Bourdieu, P. (1996), Sur la télévision, Paris, Liber.

[8]. Brohm, J.M. (2001). Le corps analyseur: essai de sociologie critique, Paris: Anthropos.

[9]. Clogston, J.S. (1990). Disability Coverage, in 16 Newspapers. Louisville, KY: Advocado Press.

[10]. Combrouze, D. (2000). L'information sur les personnes handicapées motrices et sensorielles dans les journaux télévisés. Handicap, Revue de sciences humaines et sociales, 82, 27-43.

[11]. Corcuff, P. (2007). Les nouvelles sociologies : entre le collectif et l'individuel. Ed. Armand Colin, $2^{\mathrm{e}}$ Edition

[12]. Eco, U. (1992), Les limites de l'interprétation, Paris, Grasset.

[13]. Ehrenberg, A. (1991). Le culte de la performance, Paris, Calman-Lévy.

[14]. Ehrenberg, A. (1995). L'individu incertain, Paris. Hachette.

[15]. Ehrenberg, A. (1998). La fatigue d'être soi, Paris, Odile Jacob.

[16]. Freund, K. (1974). "Male homosexuality: an analysis of the pattern." in Understanding Homosexuality: Its biological and psychological bases, edited by J. A. Lorraine. Lancaster, England: Medican and Technical Publishing Company, Inc.

[17]. Giami A., Assouly-Piquet, C. \&Berthier, F. (1988).La figure fondamentale du handicap: représentations et figures fantasmatiques, Rapport de recherche MIRE-GERAL

[18]. Giddens, A. (1994). Les Conséquences de la modernité, Paris, Harmattan.

[19]. Goffman, E. (1963). Stigmate : les usages sociaux des handicaps. Ed. Minuit, 1975.

[20]. Holtzman, L., (2000), Media Messages, New York, Armonk M.E. Sharpe.

[21]. Jones, D. (2006). The representation of female athletes in online images of successive Olympic Games. Pacific JournalismReview, 108-129

[22]. Kaufmann J. C. (2001). Ego. Pour une autre sociologie de l'individu.Une autre vision de l'homme et de la construction du sujet, Paris, Nathan.

[23]. Kaufmann, J.C. (2004). L'invention de soi. Une théorie de l'identité, Paris, Armand Colin

[24]. Kellner, D. (2003). Media Spectacle.Routeledge; Edition.

[25]. Lasch, C. (1979). The culture of narcissism: American life in an age of diminishing expectations. W. W. Norton \& Company; Revised edition (May 17, 1991).

[26]. Lazarsfeld, P.F. \& Merton, R.K. (1948). Mass communication, popular and taste organized social action. InBrysonL., (Ed.) Communication of ideas (pp.95-118). New York: Harper\&Bros.

[27]. LeBreton, D. (2005). Anthropologie du corps et modernité, Presses universitaires de France.

[28]. Léséleuc de, E. (2009). Sociologie de la réflexivité et modernité contemporaine. Construction identitaire et handicap : analyse des processus de stigmatisation/ distigmatisation des sportifs handicapés dans la presse écrite (Europe-Asie ; 2000-2008). HDR, Université Montpellier1.

[29]. Léséleuc de, E.,Pappous, A. \&Marcellini, A. (2009) (In press). La coberturamediática de las mujeres con discapacidad. Analisis de la prensacotidiana de 4 paiseseuropeosdurante los JuegosParalimpicos de Sydney 2000', Apunts. Educacionfisica y deporte, 8088.

[30]. Léséleuc de, E.,Pappous, A.,\&Marcellini, A. (2010). The media coverage of female athletes with disabilities.Analysis of the written press of four European countries during the Paralympic Games of 2000.European Journal for Sport and Society.

[31]. Léséleuc de, E \& Cherif, A \&Burlet, L \&Pappous, A. (2013 In press), De Sydney à Pékin : situation et évolution de la couverture médiathique des Jeux Paralympiques. Corps, Sport et Société.

[32]. Lipovetsky, G. \& Charles S. (2004). Les temps hypermodernes, Paris, Grasset.

[33]. Lipovetsky, G. (1983).L'ère du vide : Essai sur l'individualisme contemporain. Paris : Gallimard.

[34]. Marcellini, A. (2007). Nouvelles figures du handicap? Catégorisations sociales et dynamique des processus de stigmatisation / déstigmatisation. In Corps normalisé, corps stigmatisé, corps racialisé (pp.201-219). Paris : De Boeck.

[35]. Molénat, X., Aubert, N., Kaufmann, J.C. \& Fournier, M. (2004, Novembre). L'individu hypermoderne: vers une mutation anthropologique? Sciences Humaines, (154), 29-46.

[36]. Olivier, M.Y.\& Barnes C. (1998), Social Policy and DisabledPeople:From Exclusion to Inclusion, London, Longman.

[37]. Pappous, A., Cruz F., Leseleuc de, E., García M., Muñoz, A., Schmidt, J.\&Marcellini, A. (2007). La visibilidad de la deportistaparalimpica en la prensaespañola. Revista de CienciasdelEjercicioFísico FOB, 3 (2), 12-32.

[38]. Ruiz, J. (2005),La discapacidad como estigma: un análisis psicosocial del afrontamiento del desempleo de las personas con discapacidad física. [Electronicversion]. RedSi: revista especializada en formación y empleo de los colectivos con riesgo de exclusión, 6 .

[39]. Saliba, J. (1999). Le corps et les constructions symboliques, Socio-anthropologie .

[40]. Schantz, O. \& Gilbert, K. (2001). An Ideal Misconstrued: Newspaper Coverage of the Atlanta Paralympic Games in France and Germany.' Sociology of Sport Journal, 18, 69-94.

[41]. Smith, A.\& Thomas, N. (2005). 'The 'inclusion' of elite athletes with disabilities in the 2002 Manchester Commonwealth Games: An exploratory analysis of British newspaper coverage.' Sport, Education and Society, 49-67.

[42]. Stiker, H. J. (2007). Approche anthropologique des images du handicap : Le schème de retournement. Alter, Revue européenne de recherche sur le handicap, 1,10-22.

[43]. Zola, I.K. (1991). Communication barriers between "the able bodied" and "the handicapped". In The psychological and social impact of disability (pp.157-164). New York, NY: Springer. 